\title{
Discussion of Initial Operational Changes by Small and Medium Size Businesses in Response to the Tax Cuts and Jobs Act (TCJA) 2017
}

\author{
Micah Frankel (Corresponding author) \\ Dept. of Accounting and Finance, California State University East Bay \\ Hayward, California, United States \\ E-mail: micah.frankel@csueastbay.edu \\ John Tan \\ Dept. of Accounting and Finance, California State University East Bay \\ Hayward, California, United States
}

Received: August 13, 2018 Accepted: August 30, 2018 Published: September 16, 2018

doi:10.5296/ijafr.v8i3.13494

URL: https://doi.org/10.5296/ijafr.v8i3.13494

\begin{abstract}
Congress and the president enacted the landmark Tax Cuts and Jobs Act (TCJA) on December 22, 2017, the most sweeping change to the tax law since 1986. Tax laws such as this have a major impact on how business is conducted in the United States. This study does not attempt a comprehensive analysis of the changes in the U.S. tax code, but instead focuses on some key areas that affect most small and medium size business operators. Specifically this study examines how TCJA (2017) affects business operators in areas such as depreciation, net interest expenses, and entertainment. The Internal Revenue Service (IRS) has been continuously issuing facts sheets and statements in regards to the TCJA (2017). The first half of this study is a brief literature review on the landmark changes to the U.S. tax for corporations in regards to depreciation, net interest expenses, and entertainment. The second half of this study is a report of field observations and discussions with business operators such as a landlord of apartment complexes, a hotel operator, and a physical therapist. Though this study does not provide macro or archival data to explain how business operators responded to the TCJA (2017), field observations and discussions suggest that the three
\end{abstract}


business operators are renovating in response to full depreciation write off, reducing net interest expenses, and limiting entertainment expenses.

Keywords: Tax Cuts and Jobs Act, Business meals deduction, Depreciation, Net business interest expenses deduction, Section 163, Section 168, Section 179, Section 274

\section{Introduction}

Congress and the president enacted the landmark Tax Cuts and Jobs Act (TCJA) on December 22, 2017, the most sweeping change to the tax law since 1986. Tax laws such as TCJA have a major impact on how business is conducted in the United States. This study does not attempt a comprehensive analysis of the changes in the U.S. tax code, but instead focuses on some key areas that affect most small and medium size business operators. TCJA (2017) permits a business with inventories to use the cash method of accounting if the average annual gross receipts for the last three tax years of the business are twenty five million or less (KPMG, 2018a, p.58). Specifically this study examines how TCJA (2017) affects small and medium size business operators in areas such as depreciation, net interest expenses, and entertainment.

The authors work in the College of Business and Economics, accredited by the Association to Advance Collegiate Schools of Business (AACSB), situated on the west coast of the United States. Both authors live in a rental apartment complexes of a metropolitan city. Each apartment complex has at least sixty five units of single bedroom and double bedrooms in total. Since January 2018, both authors have noticed that his respective apartment complex has been renovating the interior common corridor areas: repainting, new carpet, new light and fixtures; and repainting the carpark area; plus laying new swimming pool tile. One author has been living in the apartment complex continuously for the last four years but has not seen any renovation to his apartment complex prior to 2018. We are curious to know if the owner's decision, of the apartment complex, to renovate was influenced by the Tax Cuts and Jobs Act (2017).

Through discussions with the owners of the apartment complexes, we have learned that the owners have decided to renovate the apartment's interior common corridor areas and retile the swimming pool etc., to take advantage of the new definition and annual limitation of section 179 as amended by the TCJA (2017). Section 179 allows a taxpayer to deduct the cost of certain type of property as expenses rather than requiring the cost of the property to be capitalized and depreciated. Before December 22, 2017, under section 179, a taxpayer could elect to immediate deduct the cost of purchase of certain type of property as expense for up to $\$ 500,000$. The TCJA (2017) increases the annual maximum amount that a taxpayer can immediately expense under section 179 from $\$ 500,000$ to $\$ 1,000,000$. Readers can read the literature section of the current paper for details of section 179 as amended by the TCJA (2017).

The research questions of this paper are:

(1) Do small and medium business operators purposely change their operations in response to 
the TCJA (2017)?

(2) When changing their business operations, in response to the TCJA (2017), do small business operators consider other macroeconomic factors?

This paper for illustration purposes, defines a small business entity (with inventories) as having average annual gross receipts for the prior three tax years of $\$ 25$ million or less; and a medium size business entity as having average annual gross receipts for the prior three tax years of more than $\$ 25$ million but less than $\$ 50$ million. In this paper, we describe how two different medium size business operators as well as owner of a small business changed their operations in response to the new TCJA (2017). Other than the apartment complex owners, the authors also have discussed the TCJA effects with the owner of a medium sized hotel chain and with the owner of a small size physical therapy business.

TCJA (2017) amends section 163(j) to limit net business interest expense to 30\% of adjusted taxable income of the business entity; effective tax years beginning after December 31, 2017. Under section 163(j) of the tax code in effect before December 22, 2017, a taxpayer could deduct all net business net interest in the tax year in which the interest was paid or accrued. The owner of the hotel chains finances capital expenditures primarily through debt and as a result is very concern with the new thirty percentage limitation of net business interest deduction. This concern is exasperated because the definition of adjusted taxable income for business interest deduction under section 163(j) changes from earnings before interest, tax, depreciation and amortization (EBITDA) to earnings before interest and tax (EBIT) starting in 2022. Due to the TCJA the hotel chain owner has already implemented a new capital budgeting plan which includes the purchase of new furnishings e.g., carpet, furniture, window treatments, fixtures etc. for use in hotel in an effort to take advantage of the new definition of personal property under section 179 as amended by law. The owner of the hotel chains also plans to use more internal equity financing and pay down business loans as much as possible, in light of macroeconomic factors especially increases in interest rates by the Federal Reserve Bank.

The owner of a small size physical therapy business expressed concern with the TCJA (2017) in regards to the repeal of any deductions for entertainment, amusement, and recreation directly related to the conduct of a taxpayer's business. The physical therapy firm's business model is highly reliant on the referral of patients by medical doctors. For tax years after 2017, the physical therapy firm can no longer deduct any expense of entertaining medical doctors for referring patients to his physical therapy business. Under the TCJA (2017), no deduction is allowed with respect to entertainment even if it is related to a taxpayer's business. As a result of the TCJA, the owner of the physical therapy firm is modifying his business model in regards to new client referrals, limiting the use of entertainment expenditures such as golfing outings with medical doctors; and the use of skyboxes for sporting events. Instead he is emphasizing other tax deductible expenses such as business meals, information sessions with food at the doctor's places of business as well as referral fees. It is his understanding that the TCJA (2017) still permits a fifty percent deduction for business meals, which are not extravagant, with business clients. 


\section{Mll Macrothink}

International Journal of Accounting and Financial Reporting

ISSN 2162-3082

2018, Vol. 8, No. 3

The Internal Revenue Service (IRS) has been continuously issuing facts sheets and statements in regards to the TCJA (2017). The first half of this study is a brief literature review on the landmark changes to the U.S. tax for businesses in regards to depreciation, net interest expenses, and entertainment. The literature review of this paper is not intended to be exhaustive; readers should refer back to the original TCJA (2017), publications of the US Treasury and Internal Revenue Service.

The goal of our literature review is to help readers to understand the logic and reasoning of why and business owners change their operations in response to the TCJA (2017). The second half of this study is a report of field observations and discussions with landlords of apartment complexes, as well as an owner of a hotel chain, and an owner of a physical therapy center. Though this study does not provide macro or archival data, in explaining how business operators responded to the TCJA (2017), field observations and discussions suggest that three different commercial operations are taking actions e.g., renovating in response to full depreciation write off, reducing net interest expenses, and avoiding entertainment expenses in response to the TCJA.

This paper contributes to the literature by providing business world readers with an updated literature review, including IRS publications, regarding such items as the net business interest deduction, immediate expensing instead of depreciating the cost of certain property, and business meal deductions. Another contribution of this paper is providing readers with actual examples of businesses that changed their operations in an effort to take advantage of the TCJA (2017). Further, this paper contributes to the literature by documenting that, all three business operations also consider several future macroeconomic factors in addition to the TCJA (2017) when adjusting their business operations. That is, all three commercial operations discussed in the paper consider macroeconomic factors such as expected interest rates, economic growth rates, inflation and changes in the tax code in their decision making.

The next section is a brief literature review. The third section discusses implications of tax law changes followed by section four which provides a report of field observation of how three different commercial businesses change operationally as a result of the TCJA. The final and last section consists of the conclusion.

\section{Literature Review}

\subsection{Limitation on Net Business Interest Deduction}

The TCJA (2017) amends section 163(j) to limit net business interest expense to $30 \%$ of adjusted taxable income of the business entity; effective for tax years beginning after December 31, 2017. This paper discusses details of amendment to section 163(j) in the following paragraphs.

On February 6, 2018, Klynveld Peat Marwick Goerdeler (KPMG) published its Tax Reform-KPMG Report on New Tax Law (KPMG, 2018a). Effective for tax years beginning after 2017, TCJA (2017) amends section 163(j) "to disallow a deduction for net business interest expense of any taxpayer in excess of 30\% of a business's adjusted taxable income plus floor plan financing interest" (KPMG, 2018a, p.48). Floor plan financing interest means 
indebtedness used to finance the acquisition of motor vehicles held for sales or lease (KPMG, 2018a, p.49). The new limitation on the deduction of net business interest expense (1) applies at the filer level rather than the taxpayer level, (2) applies only to business interest expense of the taxpayer, and (3) includes only taxable interest income in the computation of net business interest expense (KPMG, 2018a, p.51). In general, readers can interpret business interest expense and business interest income as interest allocable to a trade or business and does not include investment expense or income.

The above-mentioned new limitation on the deduction of net business interest expense does not apply to (1) taxpayers with average annual gross receipts, for the three-taxable-year period ending with prior tax year, that do not exceed \$25 million, (2) certain real estate businesses and certain farming businesses; provided that these business use the alternative depreciation system (ADS) to depreciate certain property (KPMG, 2018a, p.48-49). "Subject to the special rules for partnerships, any business interest disallowed would be carried forward indefinitely" (KPMG, 2018a, p.49). In its report (KPMG, 2018a), KPMG suggested that clarification is need over several areas in regards to business interest deduction. For example, how to address business interest income of a partnership or $\mathrm{S}$ corporation at the partner or shareholder level for the purpose of applying section 163(j) (KPMG, 2018a, p.51).

In another publication, titled Tax Reform Executive Edition: Highlights of the New Tax Law (KPMG, 2018b), KPMG explains that the definition of adjusted taxable income for business interest deduction under section 163(j) (as amended in 2017); will change from EBITDA to EBIT in the beginning of 2022 (KPMG, 2018b, p.7). EBITDA means earnings before interest, tax, depreciation and amortization. EBIT means earnings before interest and tax.

On April 2, 2018, the Internal Revenue Service published Notice 2018-28 (IRS, 2018a) providing guidance to assist taxpayers in complying with section 163(j) of the Internal Revenue Code (Code); as amended on December 22, 2017. "Section 163(j) was amended by the Act to provide new rules limiting the deduction of business interest expense for taxable years beginning after December 31, 2017 (IRS, 2018a, p.492).”

IRS Notice 2018-28 states that "For any taxpayer to which section 163(j) applies, section 163(j)(1) now limits the taxpayer's annual deduction for business interest expense to the sum of : (1) the taxpayer's business interest income (as defined in section 163(j)(6)) for the taxable years; (2) 30 percent of the taxpayer's adjusted taxable income (as defined in section 163(j)(8) for the taxable year; and (3) the taxpayer's floor plan financing interest (as defined in section 163(j)(9) for the taxable year. The limitation in section 163(j) applies to all taxpayers, except for certain taxpayers that meet the gross receipts test in section 448(c), and to all trades or businesses, except certain trades or business listed in section 163(j)(7) (IRS, 2018a, p.493)."

IRS Notice 2018-28 further states that "Section 163(j)(2), as amended by the Act, provides that the amount of any business interest not allowed as a deduction for any taxable year as a result of the limitation in section 163(j)(1) is treated as business interest paid or accrued in the next taxable year and may be carried forward. Section 163(j), as amended by the Act, does not provide for the carryforward of any excess limitation (IRS, 2018a, p.493).” 
KPMG has issued a publication (KPMG, 2018c) about IRS Notice 2018-28. As suggested in the IRS Notice 2018-28 (IRS, 2018a), Treasury and the IRS will issue proposed regulations to (1) assist taxpayers in complying with section 163(j), as amended by the law; and (2) to mandate that the calculation of the business interest expenses limitation should be at the level of a consolidated group of corporations (KPMG, 2018c, p.12-13). IRS Notice 2018-28 also clarifies that disallowed interest expense under "old section 163(j)" to be carried forwarded from the taxpayer's last tax year beginning before January 1, 2018, to the taxpayer's first tax year beginning after December 31, 2017 (KPMG, 2018c, p13). Since the new limitation on the deduction of net business interest expense applies at the filer level rather than the taxpayer level, IRS Notice 2018-28 specially states that partners in partnerships and S corporation shareholders cannot interpret newly amended section 163(j) to "double count" the business interest income of a partnership or S corporation (KPMG, 2081c, p.13).

On May 7, 2018, Ernst \& Young (EY) published The Tax Cuts and Jobs Act Tax Guide (EY, 2018a). In regards to section 163(j), as amended by the law, EY suggests that business owners should consider decreasing interest expense, increasing interest income and using financial products (EY, 2018, p.13). In section four of the current paper, the authors provide readers with some examples of business operators' responses to the new limitation on net business interest deduction.

\subsection{Section 179 Amended by TCJA (2017)}

TCJA (2017) also amends section 179; effective for property placed in service in tax years beginning after 2017. On April, 2018, IRS issued FS-2018-9 (IRS, 2018b) titled: New rules and limitations for depreciation and expensing under the Tax Cuts and Jobs Act.

TCJA (2017) increases the annual maximum amount that a taxpayer can immediately expense under section 179 from $\$ 500,000$ to $\$ 1,000,000$ and also increases the phase out amount of section 179 from $\$ 2,000,000$ to $\$ 2,500,000$. These changes to the limits of section 179 are effective for property places in service in tax years beginning after 2017 (KPMG, 2018a, p.44).

TCJA (2017), as clarified by IRS FS-2018-9, amends definition of section 179 property (1) to include tangible personal property used in connection with furnishing lodging. For example, beds and furniture for use in hotels and apartment buildings (KPMG, 2018a, p. 44), (2) to allow taxpayer to elect to include qualified improvements made to nonresidential property and placed in service after the date the property was first placed in service. "Qualified improvement property means any improvement to a building's interior. Improvements do not qualify if they are attributable to the enlargement of the building, any elevator or escalator or the internal structure framework of the building (IRS, 2018b, p.1)." Taxpayers may elect to include roofs, heating, ventilation and air-conditioning property, fire protection and alarm systems, security systems to nonresidential property placed in service after the date the property was first placed in service (KPMG, 2018a, p.44), (3) to index the $\$ 25,000$ spot utility vehicle limitation for inflation for tax years beginning after 2018 (EY, 2018, p.128) (KPMG, 2018a, p.44). 


\subsection{Section 168 ( $k$ ) Amended by the TCJA (2017)}

Section 168(k) is also amended by the TCJA (2017) in terms of the percentages of bonus depreciation and the definition of qualified property. The percentage of bonus depreciation deduction is increased from $50 \%$ to $100 \%$ for property acquired and place in service after September 27, 2017, and before 2023 (EY, 2018a, p.130) (KPMG, 2018a, p. 44). The percentage of bonus depreciation deduction will be phased down to: $80 \%$ for qualified property placed in service in 2023; $60 \%$ for qualified property placed in service in $2024 ; 40 \%$ for qualified property placed in service in 2025; and $20 \%$ for qualified property placed in service in 2026 (EY, 2018, p.130) (KPMG, 2018a, p. 44).

TCJA (2017) expands the definition of qualified property for bonus depreciation under section $168(\mathrm{k})$ to include (1) used property acquired by purchase from unrelated party and the acquiring taxpayer had never previously used the acquired property, (2) certain qualified film, television and theatrical production. A production is treated as place in service on the date of its first exhibition, broadcast or live performance to audience (EY, 2018, p.130) (KPMG, 2018a, p. 45). On the other hand, TCJA (2017) excludes property used in a trade or business from bonus-eligible qualified property under section $168(\mathrm{k})$ in the following situations: (1) property used in providing certain utility services if the rates for furnishing those services are subject to rate making by a government entity or public utility commission, (2) property used in a trade or business that has had floor plan financing indebtedness, (3) property used in in a trade or business that is not subject to the limitation of net business interest expense under section $163(\mathrm{j})$.

IRS Notice 2018-30 (IRS, 2018c), issued on May 8, 2018, details "the hypothetical cost recovery deductions used in the section 338 approach to identify recognized built-in gain or recognized built-in loss under section 382 are determined without regard to section 168(k)" (IRS, 2018c, p.1). Readers can also read IRS Rev.Proc.2018-25 (IRS, 2018d), issued on April 17,2018 , for details of depreciation limitations on luxury automobiles and personal use. Due to paper length restrictions, the current paper will not discuss both IRS Notice 2018-30 and IRS Rev.Proc.2018-25 in details.

On May 7, 2018, Ernst \& Young (EY) published The Tax Cuts and Jobs Act Tax Guide (EY, 2018). In regards to section 168(k), as amended by the law, EY suggests that business owners should consider "model out the impact that depreciation elections will have on interest deductibility (EY, 2018, p.12)." In section four of the current paper, the authors provide readers with some examples of business operators' responses to the effects of changes to section 179 .

\subsection{Business Meal Deduction Size}

TCJA (2017) amends section 274 in regards to meal and entertainment expenditures effective for amounts paid or incurred after 2017. Prior law, before December 22, 2017, a taxpayer in general could deduct fifty percent of entertainment, amusement, or recreation expenses incurred for the activities that were directly related to the active conduct of the taxpayer's trade or business (PWC, 2018, p.1). Under the TCJA (2017), no deduction is allowed with 


\section{Mll Macrothink}

International Journal of Accounting and Financial Reporting

ISSN 2162-3082

2018, Vol. 8, No. 3

respect to entertainment, regardless of its connection to the taxpayer's trade or business (PWC, 2018, p1). TCJA (2017) also provides that no deduction is allowed for membership dues for any club organized for business, pleasures, recreation, or other social purposes (KPMG, 2018a, p.54). TCJA (2017) disallows deduction for a facility or a portion of a facility used in connection with entertainment, amusement, or recreation (KPMG, 2018a, p.54).

Section 274 as amended by the TCJA (2017) still allows a fifty percent deduction for expenditures incurred in connection with client business meals provided that the taxpayer was present and such meals were not lavish or extravagant (PWC, 2018, p1; KPMG, 2018a, p.54). TCJA (2017) also reduces deduction for employer-operated eating facilities to fifty percent, and repeals employee income exclusion for qualified moving expenses reimbursements (EY, 2018a, p.18; KPMG, 2018a, p.54).

\section{Implications of Changes}

\subsection{EBITDA Versus EBIT}

The definition of adjusted taxable income to calculate the $30 \%$ limitation of net business interest expense deduction of section 163(j) will change from EBITDA to EBIT in the beginning of 2022 .

Table 1 provides readers an illustration of 30\% limitation of net business interest expense based on EBITDA and EBIT respectively. The following example is for illustration only which might not be applicable to every business operations especially partnership, farming business, and $\mathrm{S}$ corporation.

Table 1. Example of EBITDA versus EBIT limitation on net business interest deduction

\begin{tabular}{llll}
\hline Section 163(j) Amended & C corporation & EBITDA & EBIT \\
\hline Business income & $\$ 180$ & & \\
Business interest income & $\$ 10$ & & \\
Cost of goods sold & $(\$ 80)$ & & \\
Business interest expense & $(\$ 20)$ & & \\
Depreciation & $(\$ 30)$ & $\$ 60$ & $\$ 60$ \\
Taxable income before section 163(j) limitation & $\$ 60$ & $\$ 10$ & $\$ 10$ \\
Add back: net interest expense $(\$ 20-\$ 10)$ & & $\$ 30$ & - \\
Add back: depreciation & & $\$ 100$ & $\$ 70$ \\
Adjusted taxable income & & $\$ 30$ & $\$ 21$ \\
Limitation on net business interest deduction & & & \\
$30 \%$ of adjusted taxable income & & & \\
\hline
\end{tabular}

EBITDA means earnings before interest, tax, depreciation and amortization. EBIT means earnings before interest and tax. 
Table 1 demonstrates that once the definition of adjusted taxable income for business interest deduction changes from EBITDA to EBIT in the beginning of 2022, taxpayers in general will deduct a smaller amount of net business interest expense under the $30 \%$ limitation of section 163(j) as amended by law.

\subsection{Section 179}

Under the TCJA (2017) a small business entity with inventories can use cash method of accounting if the entity's average annual gross receipts of the prior three tax years is $\$ 25$ million or less (KPMG, 2018a, p.58).

This paper focuses on small and medium size businesses. Small business taxpayers in general will not elect to have immediate expense of more than one million dollar under section 179 as amended by law. While medium size business entities can use both section 179 and section $168(\mathrm{k})$ in the same tax year.

Section 179 amended by the TCJA (2017), provides some new benefits to hotel operations as well as to owners of apartment complexes. Hotel operators and apartment owners can now immediately expense all of their purchases of tangible personal property used in connection with furnishing lodging such as beds and furniture for use in hotels and apartment buildings. This paper describes two different medium size business operations taking advantages of the expanded definition of section 179 property.

A business operator cannot use section 179 deductions in a tax year to create or increase tax losses. Thus, taxpayers need to consider future business earning potential, in light of macroeconomic environment in coming years especially interest rate increases. Economies continually go through expansion and contraction cycles which affect interest rates and profits. During recessions, taxable profit might not be large enough for a business to elect section 179 and immediately expense newly acquired property.

Because the definition of adjusted taxable income for business interest is scheduled to change from EBITDA to EBIT in 2022, as shown in Table 1, taxpayers may desire to depreciate more between tax years 2018 to 2021. Taking in to account the of time value of money, ceteris paribus firms are better off electing section 179 to generate immediate expenses, and hence pay less taxes thus generating more cash in the present period. This cash can then be used to reduce debt, which is another factor for taxpayers subject to section 163(j) to consider.

\subsection{Fifty Percent Deduction of Business Meals}

The most recent publications ranging from EY (2018), KPMG (2018a), and PWC (2018) have suggested that section 274 as amended by the TCJA (2017) still allows a fifty percent deduction for expenditures incurred in connection with client business meals provided that the taxpayer was present and such meals were not lavish or extravagant.

In his article published in Tax Notes dated March 26, 2018, McBride argues that "if Congress intends to preserve the deduction for customary business meals, a statutory fix is needed because when the Tax Cuts and Jobs Act eliminated the deduction for entertainment, it also chucked the deduction for those meals (McBride, 2018, p.1)". McBride explains that "since 
section 274 was created, the term "entertainment" in section 274(a) has included business meals (McBride, 2018, p.1)".

On April 2, 2018, The American Institute of CPAs (AICPA) has written to the Department of the Treasury ("Treasury") and the Internal Revenue Service (IRS) requesting immediate guidance on the changes to Internal Revenue Code section 274 as enacted under the Tax Cuts and Jobs Act (TCJA) related to the disallowance of entertainment, amusement, recreation and qualified transportation fringe expenses (AICPA, 2018).

\section{Research Method}

The authors approach included utilizing and applying field observations, qualitative interviews and open-ended discussions for this study. Field observations included visiting business sites and observing business activities such as renovation, repainting, installation of new light and fixtures to the interior common corridor areas or carpark area of rental apartment complexes. Field observations allowed the authors to confirm compliance of the tax code in terms of deductibility requirements. For example, long-lived enhancements and modifications to elevator system do not qualify for immediate expense under section 179 (IRS, 2018b, p.1). In this regard, during field observations, the authors did not observe long-lived enhancements and modifications of the elevator in the two rental apartment complexes.

Qualitative interviews and discussions included numerous open business conversations, between the authors and the business owners on the business site locations, with a broad-based set of interview questions. The authors set out to address the two research questions of this study how and why business owners adapted and altered their business operations in response to the TCJA (2017) through the use of interviews and discussions with the business owners between January and July 2018. The business owners described and explained to the authors, how and why they modified and adjusted their business operations in response to TCJA (2017). The interviews and discussions were open-ended allowing the business owners to express their assessments, thoughts and predictions of the macroeconomic environment in relation to the TCJA (2017).

After the initial field observations, qualitative interviews and open-ended discussions were completed, the authors reviewed the findings and results and then followed up with some additional questions for further clarification as to how and why business owners adapted and altered their business operations in response to the TCJA (2017).

\section{Field Observations and Discussions}

\subsection{Owners of Apartment Complexes}

One of the authors has been continuously living in a rental apartment complex for the last four years. The owner of this apartment complex also owns several other rental apartment complexes. The owner is a medium size business operator and is subject to the section 163(j) limitation of net business interest expense to $30 \%$ of adjusted taxable income of the business entity. However, the owner is not overly concerned with the section 163(j) limitation because 
rental income generated allows the owner to renegotiate loans on favorable terms or pay them off as they come due.

Before January 2018, the apartment complexes did not undergo any renovation to the interior common corridor areas. Since January 2018, the authors have noticed that their respective apartment complexes have been renovating the interior common corridor areas: repainting, laying new carpet, preplacing lights and fixtures; and repaving the carpark area; replacing cracked concrete slabs as well as laying new swimming pool tile.

Through discussions with the owners of the apartment complexes we have learned that the owners have decided to take the above mentioned renovations in an effort to take advantage of the new annual $\$ 1,000,000$ limitation of section 179 as amended by the TCJA (2017). Interestingly, the owners do not plan to renovate the elevators of the apartment complex, because these elevator improvement do not qualify under section 179 (IRS, 2018b, p.1). Through owner interviews, the authors learned that there other macroeconomic factors were considered by the owners in addition to the new annual $\$ 1,000,000$ limitation of section 179 .

First, the owners believe that future labor shortages will increase wage rates and hence increase the costs of future renovations. For example, Bloomberg Business week reports that "In towns where workers are scare, employers are boosting pay and perks and stepping up recruiting - all while trying to avoid raising prices (Bloomberg Business week, March 15, 2018)". The owners therefore wanted to renovate in 2018 in lieu of delaying renovations which they expected would be more costly.

Second, the complex owners believe that the economy could be entering into the mature stage of the growth cycle. One owner expressed concern about a potential trade war with high tariff barriers which could lead to an economic contraction. Another owner related that during the subprime mortgage crisis recession of 2008, approximately half of his tenants lost their jobs or suffered a severe decline in their earnings and hence couldn't pay their rent. In the current operating environment, due to the strong economy, both owners have been able to consistently increase rents and still maintain high occupancy rates. Consequently, both owners have high taxable income for the 2018 tax year, and hence are electing the immediate expense of renovation cost under section 179. Both owners believe that rents are starting to level off citing increasing tenant resistance to further rent increases. Recently, CNBC reported that the "Housing market is showing signs of cracking (CNBC, July 26, 2018)". Both complex owners expressed concern that if the economy sours, they may not have enough adjusted taxable income to deduct renovation costs in the future, so it is best to act now.

Last, one apartment complex owner would like to sell his property in the near future. This owner purchased the apartment complex on 1999 for three and a half million dollars, and the apartment complex is now worth approximately ten and a half million dollars. By renovating now, the owner feels he can increase the future sales price by an amount that exceeds the after tax cost of the current renovation expenditures. 


\subsection{Hotel Operator}

The authors have had discussions with the owner of a medium sized business hotel chain. Due to large outstanding business loans, the hotel operation is constrained by IRC Section 163(j). As a result, the owner is very concerned about rising interest rates and future actions on the Federal Reserve. For example Reuters reported that Richmond Fed President Thomas Barkin stated the Federal Reserve Bank should continue its policy of increasing interest rates (Reuters, August 8, 2018). Given a rise in rates, the hotel owner is skeptical that he will be able to deduct all of the interest on his current level of outstanding debt. He stated by the time the definition of adjusted taxable income for business interest deduction under section 163(j) changes from earnings before interest, tax, depreciation and amortization (EBITDA) to earnings before interest and tax (EBIT) in the beginning of 2022 he expects his outstanding debt to be significantly lower than its current level.

As a result, instead of renovating the hotel's interior common corridor areas to take advantage of the new annual $\$ 1,000,000$ limitation of section 179 , the hotel operator is more interested in paying down his outstanding business loans. Nevertheless, the hotel operator plans to purchase new beds and furniture for use in hotel to take advantage of the new definition of personal property under section 179 as amended by law.

The macroeconomic climate significantly impacts the operations, investment decisions and hence the gross receipts of this hotel chain. Currently, the hotel chain is thriving in the expansion environment. The hotel chain is experiencing high occupancy rates primarily due to an increase in stays from price sensitive clientele ranging from truck drivers, to low budget leisure travelers. The hotel chain owner carefully monitoring the tariff, quota and trade war situation and hoping that this will not adversely affect foreign travel to the US and hence his international tourist occupancy rate. Facing uncertainty in occupancy rates, coupled with increases in wages, the hotel chain has decided to do piecemeal floor by floor renovation and piecemeal room by room redecoration. In doing so, the hotel chain will be able to generate the necessary cash to pay down outstanding business loans before the anticipated 2022 changes in section 163(j).

\subsection{Physical Therapist}

The last business analyzed is a small business size physical therapy office. Since it is a small business, the physical therapist is not subject to section 163(j) limitation of net business interest expense to $30 \%$ of adjusted taxable income of the business entity.

It is a customary practice that patients requiring physical therapy need a referral by a medical doctor. Thus this physical therapy center is highly dependent on maintaining a good relationship with the referring medical doctors. In this regard, the physical center frequently entertains referring physicians at various sporting events, concerts and golf outings. Under prior law, before December 22, 2017, a taxpayer in general could deduct fifty percent of entertainment, amusement, or recreation expenses incurred for the activities that were directly related to the active conduct of the taxpayer's trade or business (PWC, 2018, p.1).

Under the TCJA (2017), no deduction is allowed with respect to entertainment even if it is 
related to a taxpayer's business. Thus, for tax years after 2017, the physical therapy center can no longer deduct any expense for entertaining physicians for referring patients to the center. Until further clarification, the physical therapy center is assuming that the TCJA (2017) still permits a fifty percent deduction for non-extravagant business meals with business clients. Thus the center is significantly curtailing entertainment expenditures such as golfing outings, and will instead shift marketing dollars to business meals with referring doctors and onsite catered events at physician's facilities.

\subsection{Common Factors Considered by the three Different Business Operators}

Each taxpayer operates in different environments and faces different challenges, but all must deal with the constraints and opportunities of the new tax law. The three abovementioned business operations have considered some common factors while changing their business operations in response to the TCJA (2017).

Table 2. Common factors considered for business operational changes

\begin{tabular}{llll}
\hline Factors & $\begin{array}{l}\text { Apartment } \\
\text { Complex }\end{array}$ & $\begin{array}{l}\text { Hotel } \\
\text { Chain } \\
\text { Operations }\end{array}$ & $\begin{array}{l}\text { Physical } \\
\text { Therapy } \\
\text { Center }\end{array}$ \\
\hline Section 179 new $\$ 1,000,000$ annual limitation & $\mathrm{X}$ & $\mathrm{X}$ & $\mathrm{X}$ \\
Section 179 new definition of improvement like beds & $\mathrm{X}$ & $\mathrm{X}$ & \\
$\begin{array}{l}\text { Section 163(j) new 30\% limitation on net business } \\
\text { interest expense deduction }\end{array}$ & $\mathrm{X}$ & $\mathrm{X}$ & \\
$\begin{array}{l}\text { Section 163(j) effective 2022 EBIT for calculation of } \\
\text { adjusted taxable income }\end{array}$ & $\mathrm{X}$ & $\mathrm{X}$ & \\
Section 274 50\% business meal deduction only & $\mathrm{X}$ & $\mathrm{X}$ & $\mathrm{X}$ \\
Economy: boom and bust cycle & $\mathrm{X}$ & $\mathrm{X}$ & $\mathrm{X}$ \\
Future interest rate, wage gain, inflation rate & $\mathrm{X}$ & $\mathrm{X}$ & $\mathrm{X}$ \\
\hline
\end{tabular}

EBIT means earnings before interest and tax.

The authors acknowledge that the field observations and discussions (with the apartment complex owners, the owner of a hotel chain, and the owner of a physical therapy center) as described in this current paper cannot be generalized. Table 2 shows the common factors considered by the three different business operations. In order to benefit from tax deductions, taxpayers need to be generating taxable income. For example, a taxpayer cannot elect a deduction under section 179 to create a loss in that tax year. All three business operations factored in their expectations of the near term macroeconomic environment in deciding how to take the best take advantage of deductions as permitted under the TCJA (2017).

\section{Conclusion}

Congress and the president enacted the landmark Tax Cuts and Jobs Act (TCJA) on December 22, 2017, the most sweeping change to the tax law since 1986. Although this study 
does not attempt a comprehensive analysis of the changes in the U.S. tax code, it does focus on some key areas that affect most small and medium size business operations. Specifically this study examines how the TCJA (2017) affects business operations in the areas such as depreciation, net interest expense, and entertainment expenditures.

The Internal Revenue Service (IRS) has been continuously issuing facts sheets and statements in regards to the TCJA (2017). The first half of this study provided a brief literature review on the landmark changes to the U.S. tax for businesses in regards to depreciation, net interest expense, and entertainment expenditures.

Tax laws have a major impact on how business is conducted in the United States. This paper examines two research questions: (1) Do small and medium business operators purposely change their operations in response to the TCJA (2017)? (2) When changing their business operations, in response to the TCJA (2017), do small business operations consider other macroeconomic factors?

The research questions are addressed by discussions with apartment complex owners, the owner of a hotel chain, and the owner of a physical therapy center. The second half of this study is a report of field observations and discussions with the above-mentioned business owners. Although this study does not provide macro or archival data to explain how business owners responded to the TCJA (2017), field observations and discussions suggest that the business owners are renovating in response to the full depreciation write off, reducing net interest expenses, and limiting entertainment expenditures.

Due to differences in their operating environment such as competition and as well as their operating, investing and financing strategies, each taxpayer faces a different tax situation. Table 2 shows the common factors considered, by the three different business operations in changing their business operations, including the following: economic expansions and contractions, expected interest rate fluctuations, future wage increases, and the future inflation rate. All three business operations considered whether they will have adjusted taxable income which is large enough to elect deduction of expenses as permitted by the TCJA (2017).

This paper has several limitations. The field observations and discussions, as described in the paper, are not generalizable. To respect privacy, the authors do not disclose in detail the specific prior year tax return data of the business operations. In addition, the authors do not consult or do tax planning for any of the three business operations. Since the Internal Revenue Service (IRS) has been continuously issuing facts sheets and statements in regards to the TCJA (2017), this paper incorporates the available literature in regards to the TCJA (2071) at the time of writing.

This paper contributes to the literature by providing business world readers with an updated literature review, including IRS publications, about such items as the net business interest deduction, immediate expensing instead of depreciating the cost of certain property, and business meal deductions. Another contribution of this paper is providing readers with actual examples of actual businesses that changed their operations in an effort to take advantage of 
the TCJA (2017). Further, this paper contributes to the literature by documenting that, all three business operations also consider several future macroeconomic factors in addition to the TCJA (2017) when adjusting their business operations. That is, all three commercial operations discussed in the paper consider macroeconomic factors such as expected interest rates, economic growth rates, inflation and changes in the tax code in their decision making.

There are ample opportunities of future research about the TCJA (2017). The authors are looking forward to publish more articles in near future regarding how business owners modify operations in reaction to the sweeping changes initiated by the landmark TCJA (2017).

\section{References}

26 U.S.C. $\S 163(\mathrm{j})$ (as amended in 2017).

26 U.S.C. $§ 168(\mathrm{k})$ (as amended in 2017).

26 U.S.C. $\S 179$ (as amended in 2017).

26 U.S.C. $§ 274$ (as amended in 2017).

American Institute of Certified Public Accountants (AICPA). (2018). Request for Immediate Guidance Regarding IRC Section 274 - Disallowance of Certain Entertainment, Etc., Expenses. $\quad$ Retrieved July 18, 2018, from https://www.aicpa.org/content/dam/aicpa/advocacy/tax/downloadabledocuments/20180402-ai cpa-comments-sec274-meals-ent-transp-fringe.pdf

Ernst \& Young (EY). (2018). The Tax Cuts and Jobs Act Tax Guide. Retrieved July 18, 2018, from https://taxnews.ey.com/news/2018-0200-eys-guide-to-the-tax-cuts-and-jobs-act

Fed minutes: 'All' members see higher GDP and inflation, and more rate hikes. (2018, April 11). $\begin{array}{lllll}C N B C \text {. } & \text { Retrieved } & \text { July } & \text { 2018, from }\end{array}$ https://www.cnbc.com/2018/04/11/fed-minutes-all-members-see-higher-gdp-and-inflation-an d-more-rate-hikes.html

Fed's Barkin says U.S. interest rates need to rise further. (2018, August 8). Reutuers. Retrieved August 8, 2018, from https://www.reuters.com/article/us-usa-fed-barkin/feds-barkin-says-u-s-interest-rates-need-torise-further-idUSKBN1KT1LG

Housing market is showing signs of cracking: 'Anything-goes list-price strategy is no longer working'. (2018, July 26). CNBC. Retrieved July 26, 2018, from https://www.cnbc.com/2018/07/26/the-anything-goes-list-price-strategy-is-no-longer-working -in-housin.html

Internal Revenue Service (IRS). (2018a). IRS Notice 2018-28. Initial Guidance Under Section 163(j) as Applicable to Taxable Years Beginning After December 31, 2017. Retrieved July 18, 2018, from https://www.irs.gov/pub/irs-irbs/irb18-16.pdf

Internal Revenue Service (IRS). (2018b). IRS Fact Sheets FS-2018-9. New rules and limitations for depreciation and expensing under the Tax Cuts and Jobs Act. Retrieved July 
18 ,

2018

from

https://www.irs.gov/newsroom/new-rules-and-limitations-for-depreciation-and-expensing-un der-the-tax-cuts-and-jobs-act

Internal Revenue Service (IRS). (2018c). IRS Notice 2018-30. Modification of Notice 2003-65. Retrieved July 18, 2018, from https://www.irs.gov/pub/irs-drop/n-18-30.pdf

Internal Revenue Service (IRS). (2018d). IRS Rev.Proc.2018-25. 26 CFR 601.105: Examination of returns and claims for refund, credit, or abatement; determination of correct tax liability. Retrieved July 18, 2018, from https://www.irs.gov/pub/irs-drop/rp-18-25.pdf

Klynveld Peat Marwick Goerdeler (KPMG). (2018a). Tax Reform-KPMG Report on New Tax Law. Retrieved July 18, 2018, from https://home.kpmg.com/content/dam/kpmg/us/pdf/2018/02/tnf-new-law-book-feb6-2018.pdf

Klynveld Peat Marwick Goerdeler (KPMG). (2018b). Tax reform Executive Edition: Highlights of the New Tax Law. Retrieved July 18, 2018, from https://home.kpmg.com/content/dam/kpmg/us/pdf/2018/03/tnf-executive-edition-mar5-2018. pdf

Klynveld Peat Marwick Goerdeler (KPMG). (2018c). Tax Reform-Supplement to KPMG Report on New Tax. Post-Enactment Federal Guidance and Legislation. Retrieved July 18, 2018 ,

from https://home.kpmg.com/content/dam/kpmg/us/pdf/2018/06/tnf-new-tax-law-supplement.pdf McBride, G. (2018, March 26). New Tax Law Cans Business Meals: Indigestion Inevitable. Tax Notes, 1785-192.

PricewaterhouseCoppers (PWC). (2018). Taxpayers should revisit internal policies and procedures due to tax reform changes related to meal and entertainment expenditures. Retrieved July 18, 2018, from https://app.cdn.lookbookhq.com/lbhq-production/10344/content/original/c74dd517-ecad-454 4-aa70-3711c4e1fbd2/pwc-tax-reform-changes-related-to-meal-and-entertainment-expenditur es.pdf

Tax Cuts and Jobs Act. (2017, December 22). H.R. 1; Became Public Law No: 115-97. Retrieved July 18, 2018, from https://www.congress.gov/115/bills/hr1/BILLS-115hr1enr.pdf

This is what record-low unemployment looks like in America. (2018, March 15). Bloomberg Businessweek. $\quad$ Retrieved July 18, 2018, from https://www.bloomberg.com/news/features/2018-03-15/this-is-what-record-low-unemployme nt-looks-like-in-america

U.S. Consumer Sentiment Dips Due to Tariff Concerns. (2018, July 13). The Wall Street Journal. $\quad$ Retrieved July $\quad 18, \quad 2018, \quad$ from https://www.wsj.com/articles/u-s-consumer-sentiment-dips-due-to-tariff-concerns-153149191 9 


\section{Macrothink \\ International Journal of Accounting and Financial Reporting ISSN 2162-3082}

\section{Copyright Disclaimer}

Copyright for this article is retained by the author(s), with first publication rights granted to the journal.

This is an open-access article distributed under the terms and conditions of the Creative Commons Attribution license (http://creativecommons.org/licenses/by/4.0/) 